\title{
Nutritional requirements of freshwater ornamental fish: a review
}

\author{
Requerimientos nutricionales de peces ornamentales de agua \\ dulce: una revisión
}

\begin{abstract}
Yohana Velasco-Santamaría, ${ }^{1 *}$ Ph.D, Wilson Corredor-Santamaría, ${ }^{1}$ M.Sc(c).
${ }^{1}$ Universidad de los Llanos, Instituto de Acuicultura (IALL), Research Group on Reproduction and Toxicology of Aquatic Organisms (GRITOX), Km 12 vía Puerto López, Villavicencio, Meta, Colombia. *Corresponding: ymvelasco@yahoo.com.
\end{abstract}

Recibido: Junio de 2010; Aceptado: Febrero de 2011.

\begin{abstract}
The knowledge of nutritional requirements in ornamental fish species is essential to improve the productive development; however, the nutritional information of these species is scarce and sometimes this information is extrapolated from results obtained from nonornamental fish species. In ornamental fish, a correct formulation of the diet improve the nutrient digestibility and supply the metabolic needs, reducing the maintenance cost and at the same time the water pollution. Inert food such as meal powder, flakes, milk powder, bovine heart and liver, tubifex worms, as well as live food including Artemia sp., rotifers and Moina have been used extensively in ornamental fish feeding with a diverse range of nutritional values and productive properties. In contrast with farmed fish, skin pigmentation is a mandatory characteristic in ornamental fish and the use of dietary supplements with carotenoids is recommended. The aim of this document is to review the specific nutritional requirements which are indispensable to improve economical and productive potential of freshwater ornamental fish.
\end{abstract}

Key words: Aquarium fish, carotenoids, energy, lipids, ornamental fish, protein, vitamins. (Sources: AIMS, CAB). 


\section{RESUMEN}

El conocimiento de los requerimientos nutricionales en peces ornamentales es esencial para su desarrollo productivo; sin embargo, la información nutricional en estas especias es limitada y algunas veces es extrapolada de resultados obtenidos de otras especies de peces no ornamentales. En peces ornamentales, una correcta formulación en la dieta mejora la digestibilidad nutricional y suple las necesidades metabólicas, reduciendo por tanto los costos de mantenimiento y la contaminación del agua. Alimentos inertes como comida en polvo, hojuelas, leche en polvo, corazón e hígado de bovino, gusanos tubifex así como alimento vivo tales como Artemia sp., rotíferos y Moina han sido usados extensivamente en la alimentación de peces ornamentales, con un amplio rango de valores nutricionales y propiedades productivas. A diferencia de las especies de cultivo, la pigmentación de la piel es una característica imprescindible en peces ornamentales y por tanto el uso de suplementos con carotenoides es recomendado. En conclusión, conocer los requerimientos nutricionales específicos para cada especie de peces ornamentales es indispensable para optimizar su potencial económico y productivo en la acuicultura.

Palabras clave: Carotenoides, energía, lípidos, peces de acuario, peces ornamentales, proteína, vitaminas. (Fuente: AIMS, CAB).

\section{INTRODUCTION}

The production and trade of ornamental fish is a profitable alternative in the aquaculture sector. Freshwater and marine species have been used successfully in the aquarium fish trade, being the most popular: discus (Symphysodona equifaciatus), guppy (Poecilia reticulata), swordtail (Xiphophorus helleri), molly (Poecilia sphenops, Poecilia latipinna) and goldfish (Carassius auratus) (1). Despite the economical importance of this sector, the nutritional information for ornamental fish is scarce and often few or even no data of the nutritional requirements is available $(1,2)$. Guppy and goldfish are the most studied freshwater fish species (1), and true percula clownfish (Amphiprion percula) is considered as reference in nutritional studies in marine species (3).

In natural conditions, fish can regulate and maintain their food intake and therefore their nutritional requirements, reducing the possibility of suffering nutritional deficiencies; however, this problem can be observed when the fish are subject to confinement conditions (4). Most of the information is not specific to ornamental fish because it has been based on results from farmed fish kept under different farming conditions, nutritional requirements, feeding habits and type of food. Therefore, the limited information about nutrient digestibility in ornamental fish increases the maintenance costs and the water pollution (3).

Taking into account the above, the aim of this article is to review the information available in the nutrition of freshwater ornamental fish with special emphasis on their nutritional requirements and feeding alternatives and to highlight the need to carry out more research in this relevant area.

Nutritional requirements in ornamental fish. Lovell (4) reported that there are some factors that differentiate the nutritional requirements in fish e.g. they can absorb minerals through the gills and some fish require more dietary unsaturated fatty acids and vitamin C. Despite ornamental fish are known worldwide, the determination of nutritional requirements has not been studied deeply and it has based on the information from other species such as finfish used in aquaculture (4). One advantage of ornamental fish over farmed fish is the low amount of food required e.g. feeding requirements fluctuated from $3.8 \mathrm{mg}$ feed/day/g BW in Neon tetra (Paracheirodoninnesi) to $25.79 \mathrm{mg}$ feed/ day/g BW in goldfish (5). 
Energy. The energy required for maintenance and protein synthesis in fish is less than in mammals (4); therefore, the protein:energy ratio in fish is higher mainly due to the low levels of energy requirements. It is important to highlight that the food intake in fish is closely related to its energy requirements e.g. a decrease in feeding was observed in Cichla sp. at higher digestible energy (DE): brute protein (BP) ratios due to the fact that high dietary energy induce satiety (6). It was also observed that fish fed with low DE:BP ratio had a higher protein deposition due to the increase in the protein consumption (6). Based on that, it is possible to suggest that fish can use its dietary protein to maintain the energetic requirements at the expense of growth. Table 1 shows the energy requirements in some species of freshwater ornamental fish.

Proteins and amino acids. The dietary protein level influences the body weight in several fish species $(7,8)$. The crude protein requirements in many fish species generally range between 25 to 55\% (9) (Table 1).

The classification of the amino acids is based on both the body's ability to synthesize them and to meet the metabolic requirements which allow their classification into unessential and essential amino acids. Most animals including fish species require 10 essential amino acids namely arginine, histidine, isoleucine, leucine, lysine, methionine, phenylalanine, threonine, tryptophan and valine (9). The essential amino acid requirements in goldfish vary from $3.4 \%$ to $11.8 \%$ (10) which are higher than those reported in Japanese eel (Anguilla japonica), common carp (Cyprinus carpio), Channel catfish (Ictalurus punctatus) and Chinook salmon (Oncorhynchus tshawytscha, $0.5 \%$ to $6.0 \%)(9)$.

According to Elangovan and Shim (11), the comparison of protein requirements between fish species is complex since this can vary according to the size and life stage, diet formulation or farming condition. In Red tailed tinfoil (Barbodes altus), the optimal dietary protein level has been reported to be $41.7 \%$ with positive effect on weight gain. Despite the increase in the protein deposition of around $40 \%$, this trend was not constant. A significant decrease in the body weight was observed with protein level around $50 \%$ due to the animal limitations to use the protein and their reduced feed efficiency (11).

Table 1. Protein and energy requirements in some freshwater ornamental fish species. The protein source is shown in parenthesis.

\begin{tabular}{|c|c|c|c|c|c|}
\hline Scientific name & Common name & Weight (g) & Energy $(\mathrm{kJ} / \mathrm{g})$ & $\begin{array}{l}\text { Protein } \\
\text { requirements (\%) }\end{array}$ & Reference \\
\hline Arapaima gigas & Pirarucu & $120.7 \pm 3.5$ & $23.63 \mathrm{GE}(564.5 \mathrm{kcal} / 100 \mathrm{~g})$ & $48.6(F M-S)$ & Ituassú et al (12) \\
\hline Barbodes altus & Tin foil barb & 0.812 & $20.38 \mathrm{GE}$ & $41.7(\mathrm{C})$ & $\begin{array}{l}\text { Elangovan and } \\
\text { Shim (11) }\end{array}$ \\
\hline \multirow{2}{*}{ Carassius auratus } & \multirow{2}{*}{ Goldfish } & 0.2 & $11.72 \mathrm{DE}$ & $29(F M-C)$ & $\begin{array}{l}\text { Lochmann and } \\
\text { Phillips (13) }\end{array}$ \\
\hline & & 0.008 & $20.3 \mathrm{GE}$ & $53(F M-C)$ & $\begin{array}{c}\text { Fiogbé and } \\
\text { Kestemont (10) }\end{array}$ \\
\hline Cichlasoma synspilum & Redhead cichlid & 0.28 & 1.55 DE & 40.81 (FM) & $\begin{array}{c}\text { Olevera-Novoa et } \\
\text { al (14) }\end{array}$ \\
\hline Cichla sp. & Tucunaré & $10-30$ & $14.65 \mathrm{DE}(3500 \mathrm{kcal} / \mathrm{kg})$ & $37-41(F M-F E-S)$ & Sampaio et al (6) \\
\hline Colisa Ialia & Dwarf gourami & NR & NR & 25 & Shim et al (15) \\
\hline Poecilia reticulata & Guppy & 0.1 & 13.10 ME & $30-40(F M-C)$ & $\begin{array}{l}\text { Shim and Chua } \\
(16)\end{array}$ \\
\hline Pterophyllum scalare & Angelfish & $2.33 \pm 0.26$ & 12.97 DE (3100 kcal/kg) & $26(S-C M)$ & Zuanon et al (17) \\
\hline \multirow[t]{2}{*}{ Symphisodon aequifasciata } & Discus & $4.45-4.65$ & $21.65 \mathrm{GE}$ & $44.9-50.1(F M-C)$ & Chong et al (18) \\
\hline & Swordtails, 6 - 8 weeks & NR & NR & $45 \%(F M-S)$ & Kruger et al (19) \\
\hline \multirow[t]{2}{*}{ Xiphophorus helleri } & Females, $20 \mathrm{wk}$ & $1.1-1.2$ & $16.5 \mathrm{GE}$ & $30(F M-C)$ & Chong et al (8) \\
\hline & Females, $20 \mathrm{wk}$ & $0.8-0.9$ & $20.9 \mathrm{GE}$ & $30(\mathrm{FM}-\mathrm{KM})$ & Ling et al (7) \\
\hline
\end{tabular}

NR: not reported. GE: gross energy; ME: metabolizable energy; DE: digestible energy; FM: fish meal; C: casein; CM: corn meal; FE: fish egg; S: soybean; KM: krill meal. 
The protein source is also an important factor to be consider in the diet formulation. Marine protein sources were more efficiently to induce the weight gain in neon tetra (Paracheirodon innesi) than diets based on vegetable proteins; however, fish fed with both protein sources diets containing $45 \%$ or $55 \%$ crude protein showed a better growth performance than $25 \%$ crude protein diets (20). These authors confirm the need to carry out additional studies on the nutritional requirements of ornamental fish species using mainly vegetable protein sources to reduce the productive cost.

The life stage also affects the protein requirements level, for example in juvenile goldfish the protein requirement is lower $(29 \%)$ than larvae $(53 \%)(10,13)$. These authors suggest that this difference can be explained by the faster growth in larvae over a shorter period, and the physiological characteristics such as the inadequate selection of protein in larvae.

The species of Poeciliidae family including guppy, molly, red swordtail and platies (Xiphophorus maculatus) are the most popular ornamental fish produced in Singapore, Malaysia, Indonesia, Thailand, India and China; consequently, the broodstock nutrition is considered as an important factor in the reproductive performance in most fish species (8). In this respect, increases in the relative fecundity as well as fry production of $X$. helleri were observed in larvae from females fed with very high level of protein $(>30 \%)(7,8)$. However, effects of the dietary protein on fry length and weight were not observed (8). These authors concluded that $30 \%$ of dietary protein could be used to guarantee the fry production.

Lower protein levels (20\%) produce lower protein content in muscle and ovary tissue in swordtail $(7,8)$, which could be explained by the utilization of the body protein reserves and hence deficiency in protein for corporal growth and oocyte development. This is in agreement with Afzal Khan et al (21) who observed that fish fed with low dietary protein had lower egg protein content. Similarly, decreases in the ovarian mass was observed in fish fed with $20 \%$ of dietary protein as a result of poor oocyte development; in contrast, the hepatosomatic index was higher in fish fed with $30 \%$ of dietary protein level, probably as a mechanism to improve the vitellogenesis (7).

Chong et al (18) suggested that discus ( $S$. aequifasciata) has high protein requirements due to its carnivorous habits. In this species, casein, fish meal and bovine heart provided a high dry matter digestibility whereas wheat meal and soybean produced the low values. On the other hand, the high protein digestibility has been observed in diets contained casein but also in diets with fish meal, soybean and bovine heart (22). The use of bovine heart is a common practice in fish farms as a main ingredient in preparation of moist feed diets in ornamental fish. Chong et al (22) also suggested that this kind of food could be used as a major dietary protein source for commercial discus farming.

To avoid water pollution, the ornamental fish require an efficient utilization of the dietary protein to minimize the ammonia excretion (3). Therefore, new alternatives of fish meal replacement have been studied, with soybean meal being a good option due to its high protein level and satisfactory growth results (3). However, high levels of soybean incorporation in the diet of discus lead to reduction in the food intake due to low palatability and decreased digestibility, therefore longer periods of acclimatization are recommended to avoid this problem $(1,22)$.

Lipids and essential fatty acids. According with Sales and Janssens (3), the lipids are important sources of energy and fatty acids which are essential for normal growth and fish survival. In general, most fish require unsaturated fatty acids with long chains; nevertheless, the requirements vary according to the species with the most essential n-3 and n-6 fatty acids (4). Freshwater fish require linoleic acid (18:2 $n-6)$ or linolenic acid (18:3n-3) whereas seawater species require eicosapentaenoic acid (20:5 n-3) and docosahexaenoic acid $(22: 6 n-3)(9)$. Despite the physiological 
importance of fatty acids, the information on the requirements of ornamental fish is scarce (3). Marine oils and some vegetable oils are the main source of lipids in fish food; however, the high cost and easy oxidation of marine oils have motivated the use of alternative sources.

Ling et al (7) suggested that the muscle lipid content acts as a source of lipid in the ovary, making it a useful indicator of reproductive performance. Increases in dietary lipid from $8 \%$ to $16 \%$ with the same protein level, improved the growth performance in swordtail. The muscle lipid content had the same trend as the protein level, with the highest accumulation observed with the highest dietary lipid (7). In eastern mosquitofish (Gambusia holbrooki), a clear relationship between diet lipids and mobilization of ovary lipids during vitellogenesis improve the reproductive performance (23). In contrast, in the lipid content did not influence the gonadosomatic and hepatosomatic index in $X$. hilleri (7).

Alternative food including tubifex worms, mosquito larvae and bovine liver and heart are offered frequently in some freshwater ornamental fish with the aim to improve the reproductive maturation and spawning $(22,24)$. In this respect, Tamaru et al $(24)$ reported that bovine liver and mosquito larvae had the highest composition levels of fatty acids ( 8.96 and $8.27 \mathrm{mg} / 100 \mathrm{mg}$ dry weight, respectively); however, all of the live food and fresh food preparations evaluated showed deficient and lower levels of 22:6(n-3) than bovine heart. The most common fatty acids in alternative diets are 18:2 (n-6) and 20:4 (n-6) which are involved in the reproductive physiology since they are prostaglandin precursors which are important in the ovulation process (24).

Frequently fish farmers use live food such as tubifex worms, blood worms and freshly prepared foods including bovine liver and heart, cockles and shrimps as protein sources (22). The composition of essential fatty acids in some of these alternative food is shown in the table 2 .

Carbohydrates. In ornamental fish the information about carbohydrate metabolism and its function remain unknown compared to the broad knowledge in other fish species. The hydrolysis of $\mathrm{CHOn}$ in the intestinal mucosa produce monosaccharides that are easily absorbed with glucose the most important sugar; however, the real role of $\mathrm{CHOn}$ and glucose in fish is uncertain (9). CHOn could be a cheaper source of energy than protein and lipids (3); however, the dietary carbohydrate requirements in fish has not been demonstrated clearly.

Although in ornamental fish the information about carbohydrate metabolism is limited, some physiological and biochemical function has been found in other fish species. In some carnivorous fish, increases in starch above $10 \%$ of dietary dry matter reduce the food utilization and the fish are unable to control efficiently the glucose concentration. The CHOn are involved in the secretion and activity of insulin and glucagon

Table 2. Essential fatty acids contained in alternative food used in freshwater ornamental fish. Values are expressed in $\mathrm{mg} / 100 \mathrm{mg}$ dry weight. From Tamaru and Ako with permission (24).

\begin{tabular}{cccccccc}
\hline Fatty acids & Bovine heart diet* & Bovine liver & Black tubifex & Red tubifex & Moina & Earthworms & Mosquito larvae \\
\hline $18: 2 \mathrm{n}-6$ & 1.71 & 1.56 & 1.68 & 1.43 & 0.11 & 0.11 & 0.48 \\
$20: 4 \mathrm{n}-6$ & 0.51 & 0.22 & 0.90 & 0.64 & 0.16 & 0.22 & 0.33 \\
$18: 3 \mathrm{n}-3$ & 0.2 & 0.0 & 0.51 & 0.19 & 0.04 & 0.10 & 0.31 \\
$20: 5 \mathrm{n}-3$ & 0.11 & 0.0 & 0.61 & 0.33 & 0.07 & 0.09 & 0.23 \\
$22: 6 \mathrm{n}-3$ & 0.33 & 0.0 & 0.0 & 0.0 & 0.0 & 0.0 & 0.0 \\
Total FA & 4.86 & 8.96 & 6.22 & 4.68 & 4.22 & 0.81 & 8.27 \\
\hline
\end{tabular}

*Bovine heart contains $0.33 \mathrm{mg} / 100 \mathrm{mg}$ dry weight of $22: 6 \mathrm{n}-3$. This essential fatty acid was absent in the other kind of food (0). 
and in less proportion in the growth hormones. One of the most important pathways is the intake of $\mathrm{CHOn}$ in the pentose phosphate cycle to produce NADPH, which is essential for the fatty acid biosynthesis. Therefore $\mathrm{CHOn}$ are considered as a precursor of lipogenesis and stimulate the fat deposition. For instance, at low temperatures the pentose cycle is activated in some fish species and in other species the prolonged food deprivation stimulates the efficient utilization of the stored hepatic glycogen (25).

Despite the above findings, Krogdahl et al (26) reviewed the carbohydrate digestion and physiological mechanism in fish concluding that with the current information it is impossible to elucidate the real digestibility and nutrient utilization of carbohydrates, emphasizing the need to carry out additional studies in this area.

Minerals. Lovell (4) states that, in general, the mineral supplementation in fish is reduced since they can absorb these minerals through the gill membranes and intestinal epithelium; which could explain the few studies regards mineral requirements in fish. It has been observed in guppy, that the required magnesium level for optimal growth is $0.54 \mathrm{~g} / \mathrm{kg}$ of diet (27). The most important minerals include calcium, phosphorus, copper, iodine, iron, magnesium, manganese, selenium and zinc (4). Within these, phosphorus is commonly supplemented since it is essential in growth, bone mineralization and lipid and carbohydrate metabolism (3) and because its concentration in water is low (4). Some clinical manifestations of phosphorus deficiency in guppy include depressed appetite, scoliosis and lordosis has been observed (28).

Vitamins. Based on Lovell (4), most fish species require vitamin supplementation which vary according to species, fish size, food rates, environmental factors, nutrient interrelationships or health condition. Essential vitamins in some metabolic and corporal enzymatic reactions are commonly supplemented in the diet.
Vitamins $\mathrm{E}$ and $\mathrm{C}$ are considered antioxidants owing to their ability to reduce the stress response in fish (29). Vitamin C is essential in many metabolic processes including collagen synthesis (tissue repair), protection of cell membranes, metal absorption and detoxification of xenobiotics. In addition, vitamin $C$ is considered an intra- and intercellular reducing agent. It is known that, the concentration of ascorbic acid affects the mixed-function oxidases activity that are involved in the metabolism of xenobiotics (30).

Vitamin $C$ is supplemented using ascorbic acid (AA) as a source. Its deficiency in fish can produce deformities in opercula and jaws, lordosis, growth reduction and hemorrhage in eyes and fins $(4,31)$. In addition, erosion of the skin and fins, exophthalmia, swollen abdomen and dark coloration has been reported in mayan cichlid (Cichlasoma urophthalmus) (32). Fracalossi et al (31) reported that oscar (Astronotus ocelatus) without AA supplementation showed reduced weight gain and deformities in the cartilage supporting the gills and the vertebral column due to the decrease in collagen content. Therefore, these authors concluded that $25 \mathrm{mg} \mathrm{AA} / \mathrm{kg}$ diet is sufficient to prevent the clinical manifestation of vitamin C deficiency. Blom and Dabrowski (2) reported no effects on mortality, macroscopic alterations or negative effects on growth performance in angelfish (Pterophyllumscalare) fed with concentrations of ascorbic acid between 30 to $1440 \mathrm{mg} / \mathrm{kg}$ diet during 96 days.

In angelfish, ascorbic acid levels above 360 $\mathrm{mg} / \mathrm{kg}$ diet increased the liver AA level; in contrast, diets with less than 120 mg AA/ $\mathrm{kg}$ diet showed the lowest AA concentration (2). To keep the maximum liver storage of vitamin $\mathrm{C}$, angelfish juveniles require higher $A A$ levels than the requirements of vitamin $C$ in other ornamental fish such as Oscars (Astronotus ocellatus) and Mexican cichlids and farmed fish like catfish (11 $\mathrm{mg} A \mathrm{~A} / \mathrm{kg}$ ) and tilapia aurea (50 mg AA/ $\mathrm{kg}$ ) (Table 3). 
Table 3. Vitamin A and $\mathrm{C}$ requirements in four ornamental fish species.

\begin{tabular}{|c|c|c|c|c|}
\hline Scientific name & Initial weight (g) & Vitamin C $(\mathrm{mg} / \mathrm{kg})$ & Vitamin A $\quad(\mathrm{IU} / \mathbf{k g})$ & Reference \\
\hline Cichlasoma urophthalmus & $0.16-0.17 \mathrm{mg}$ & $\begin{array}{l}40 \text { (growth) } \\
110 \text { (health) }\end{array}$ & NR & Chávez de Martínez (26) \\
\hline Astronotus ocellatus & $29.1 \pm 1.9$ & 25 & NR & Fracalossi et al (25) \\
\hline Poecilia reticulata & NR & NR & $2000-4000$ & Shim and Tan (33) \\
\hline Pterophylum scalare & $1.12 \pm 0.08$ & 360 & NR & Blom and Dabrowski (2) \\
\hline
\end{tabular}

NR: not reported.

The activity of L-ascorbic acid is timedependant and oxidation labile, making necessary to keep a fresh diet preparation $(4,30)$. In ornamental fish food, it is possible to find L-ascorbic-2-phosphate which is incorporated into commercial diets (ascorbic acid phosphate; 4). Other sources of vitamin $C$ which are more stable and resistant to oxidation include L-ascorbic-2-sulphate, ascorbic2-glycoside and ascorbate-6-palmitate (24). However, the selection of the vitamin $\mathrm{C}$ form depends on the diet, fish size, fish species, husbandry and cost.

\section{Carotenoids and their role in the colour enhancement. Dietary carotenoids and} carotenoid-protein complexes are the main source of fish skin and muscle pigmentation $(3,4,34)$; therefore, to increase the skin and flesh colour in captivity, fish must obtain an optimum level of carotenoids in their diet (35). Fish skin colour is mainly attributed to the presence of chromatophores that contain pigments including melanins, pteridines, purines and carotenoids (34).

Since fish, like other animals, do not biosynthesize carotenoids de novo, it is essential to provide them with dietary supplements to allow the storage in tissue and teguments (34). Carotenoids are only synthesized by plants, phytoplankton (microalgae), zooplankton and crustaceans; therefore, the primary productivity in ponds directly affects the skin pigmentation due to the availability of natural or life food to synthesized these compounds (4). Wallat et al (36) reported that fish skin colour pigmentation is faster in pond-water-reared than in those fish reared in well water.
The most common carotenoids in freshwater include astaxanthin, zeaxanthin, xanthophylls, lutein, a- and $\beta$-carotene, taraxanthin and tunaxanthin (9). Wang et al (37) report that in Serpae tetra (Hyphessobrycon callistus), astaxanthin is the main body carotenoid and most of the dietary $\beta$-carotenoid are converted and stored as astaxanthin into the body.

The carotenoid has a variety of functions including antioxidant, inducer of provitamin A activity, enhancing immune response, reproduction, growth, maturation and photoprotection (35). It has been shown, in flame-red dwarf gourami (Colisa lalia) that inclusion of synthetic astaxanthin in the diet enhance the red skin coloration stimulating sexual behaviour (38). In terms of immune response, decrease in superoxide dismutase (SOD), glutathione peroxidise (GTP), aspartate and alanine transaminase activities were observed with increased dietary carotenoid concentration, suggesting a possible antioxidant capacity and liver protection (37).

The cost of synthetic pigments has encouraged the research of natural compounds such as yeast, marine bacteria, green algae and even plants extracts as a pigment sources. In this respect, Chlorella vulgaris has been the most effective to improve the skin colour intensity in ornamental fish $(39,40)$. The great bioavailability and the thin cellular membrane are the variables that contribute to the high efficiency of $C$. vulgaris. However, there is still difference in terms of pigmentation between natural and synthetic sources. Supplementation with C. vulgaris showed good skin pigmentation in goldfish but the best pigmentation rates were observed in fish fed with astaxanthin 
diets (40). Shina and Asimi (35) evaluated in goldfish four natural carotenoid sources (Spirulina, China rose petals, Marigold petals and Lactobacil a at $5 \mathrm{mg} / \mathrm{kg}$ ) showing that China rose petals as the most effective to enhance skin pigmentation and improve gonadal development. In contrast, Ezhil et al (41) evaluated the use of marigold petal meal in swordtail concluding that this lutein can be used as a pigmenting source. The supplementation with natural or synthetic dietary carotenoid in some fish species did not stimulate neither the growth, feed efficiency nor survival $(37,39,40,41)$. Therefore, owing to the carotenoid nutritional value is often lower than traditional diets, protein supplementation with this dietary source is highly recommended.

Live food as an alternative to improve
ornamental fish production. Lim et al (42) states that the efficiency in the production of fish larvae, fry and fingerlings are related with the accessibility to live food for feeding purpose. Suitable quantities of live food have contributed to the success in most of the marine fish species; however, the production in freshwater fish has been limited due to the reduced availability of live food (42).

Various types of macro- and micro-live food used in marine and freshwater fish species included Artemia nauplii, rotifers, bloodworm, Tubifex, mosquito larvae, Daphnia and Moina $(22,24,42)$. Rotifers are suitable for the first feeding in fish larvae due to their small size, slow swimming and nutritional quality. The principal marine and freshwater rotifers used are Brachyonius plicatilis and $B$. calcyflorus, respectively (42). The common live food offered after rotifer feeding is Artemia nauplii, a marine species used massively in marine and freshwater fish because it's high nutritional properties; however, it's high productive cost is a disadvantage (42). In this respect, Lim et al (43) proposed the use of decapsulated cysts as a substitute for Artemia nauplii or Moina in freshwater ornamental fish, showing a better growth performance, survival and stress resistance as well as a low cost and better hygienic procedure. Finally, on-grown Artemia has produced high performance when bigger ornamental fish are fed (42). The feeding of clown fish (Amphiprion percula) fry with dry feed showed similar survival rate to fish fed with Artemia (44); however, this species could only efficiently digested the artificial food from 9 days post hatching (45).

Food preparation for ornamental fish. Coutinho et al (46) reported that the inert diets used in the nutrition of marine fish larvae have been formulated with a similar composition to live food; some of these inert diets include algae, yeast, blood, egg, heart and mammal liver and fish muscle which are suitable sources of nutrients. As previously stated, algae, rotifers and Artemia nauplii are the most common food for ornamental fish larvae, especially for larvae from small eggs due to the yolk sac is consumed faster once hatching, and in this period the digestive tract is unable to receive inert food (4). In larvae with small mouths, supplementation with egg yolk suspension, milk powder or powdered food and small plankton are used routinely (42).

Usually during the first week the larvae are fed with live food or a mix with an inert food with the aim to subsequently increase the ingestion of dry food. In this step, powder meal is supplemented with vitamins and oil to reduce the losses of nutrients into the water (4). Another alternative is to offer pellets with a gradual increase in the size according to the larvae age (4). A suitable growth rate and maintenance has been observed in angelfish fed with extruded and pellet diets (4000 kcal/ $\mathrm{kg}$ and $28 \%$ protein); however, fish fed with ground diet showed poor growth and smaller specific growth rate (47). In contrast, higher growth was observed in guppy fed with powdered food rather than flake food, probably due to the fish ability to consume the food quickly, preventing the leaching of vital nutrients from the food (48).

One of the problems is owing to the fact that different ornamental fish species are often kept in the same aquarium or tank, making difficult to supply the nutritional requirements for each particular species 
taking into account the physiological and morphological characteristics as well as the feeding habits (45). Due to these factors, feeding fish in aquarium on a speciesspecific basis is impractical and therefore diet extrapolation has been a common practice in the aquariophily.

Final remarks. The scarce knowledge about nutrient requirement and digestibility in ornamental fish has led to extrapolate the information available from farmed fish without consider the species-specific requirements; therefore, this practice could lead to affect negatively the growth performance, phenotype and physiology.
Taking this review into account, we highlight the need to carry out studies in native ornamental fish or ornamental species with commercial interest in order to fulfill their optimum nutritional requirements, promote optimal growth, reduce the cost and food waste, and minimize the water pollution. Moreover the traditional parameters used in aquaculture to evaluate diet formulation such growth performance and reproduction, is required to consider diets containing carotenoids to enhance the skin and flesh pigmentation. Finally, based on the importance of the live food as a source of fatty acids, protein and vitamins, it is highly recommended to carry out research in this area to improve the production of live food and to supply the food demand.

\section{REFERENCES}

1. Chong A, Hashim R, Ali Ab. Assessment of soybean meal in diets for discus (Symphysodon aequifasciata HECKEL) farming through a fishmeal replacement study. Aquacult Res 2003; 34(11): 913-922.

2. Blom JH, Dabrowski K. Vitamin $C$ requirements of the Angelfish Pterophylum scalare. J World Aquacult Soc 2000; 31(1): 115-118.

3. Sales J, Janssens GPJ. Nutrient requirements of ornamental fish. Aquat Living Resour 2003; 16(6): 533-540.

4. Lovell RT. Nutrition of ornamental fish. En: Bonagura J (Ed.), Kirk's Current Veterinary Therapy XIII-Small Animal Practice. W.B. Saunders, Philadelphia, USA; 2000, p. 1191-1196.

5. Pannevis MC, Earle KE. Maintenance energy requirement of five popular species of ornamental fish. J Nutr 1994; 124(Suppl): 2616-2618.

6. Sampaio AMBM, Kubitza F, Cyrino JEP. Relação energia: proteína na nutrição do tucunaré. Scientia Agricola 2000; 57(2): 213-219.
7. Ling S, Hashim R, Kolkovski S, Chong Shu-Chien A. Effect of varying dietary lipid and protein levels on growth and reproductive performance of female swordtails Xiphophorus helleri (Poeciliidae). Aquacult Res 2006; 37(13): 1267-1275.

8. Chong ASC, Ishak SD, Osman Z, Hashim R. Effect of dietary protein level on the reproductive performance of female swordtails Xiphophorus helleri (Poeciliidae). Aquaculture 2004; 234(1-4): 381-392.

9. N.R.C. Nutrient Requirements of Fish. Washington, D.C, USA.: National Academy Press; 1993.

10. Fiogbé ED, Kestemont P. An assessment of the protein and amino acid requirement in goldfish (Carassius auratus) larvae. J Appl Ichthyol 1995; 11(3-4): 282-289.

11. Elangovan A, Shim KF. Growth response of juvenile Barbodes altus fed isocaloric diets with variable protein levels. Aquaculture 1997; 158(3-4): 321-329. 
12. Ituassú $D R$, Filho $M P$, Roubach $R$, Crescêncio R, Cavero BAS, Gandra AL. Níveis de proteína bruta para juvenis de pirarucu. Pesq Agropec Bras Brasília 2005; 40(3):255-259.

13. Lochmann RT, Phillips H. Dietary protein requirement of juvenile golden shiners (Notemigonus crysoleucas) and goldfish (Carassius auratus) in aquaria. Aquaculture 1994; 128(34): 277-285.

14. Olevera-Novoa MA, Gasca-Leyva E, Martinez-Palacios CA. The dietary protein requirements of Cichlasoma synspilum Hubbs, 1935 (Pisces: Cichlidae) fry. Aquacult Res 1996; 27(3): 167-173.

15. Shim KF, Landesman $L$, Lam $T J$. Effect of dietary protein on growth, ovarian development and fecundity in the dwarf gourami, Colisa lalia (Hamilton). J Aquacult Trop 1989; 4(1):111-123.

16. Shim KF, Chua YL. Some studies on the protein requirement of the guppy, Poecilia reticulata (Peters) J Aquar Aquat Sci 1986; 4(4):79-84.

17. Zuanon JAS, Salaro AL, SilveiraMoraes SS, de Oliveira-Alves LM, Balbino EM, Siqueira Araújo E. Dietary protein and energy requirements of juvenile freshwater angelfish. Rev Bras Zootecn 2009; 38(6):989-993.

18. Chong ASC, Hashim R, Ali AB. Dietary protein requirements for discus (Symphysodon spp.). Aquacult Nutr 2000; 6(4):275-278.

19. Kruger DP, Britz PJ, Sales J. Influence of varying dietary protein content at three lipid concentrations on growth characteristics of juvenile wordtails (Xiphophorus helleri Heckel 1848). Aquar Sci Cons 2001; 3(1):275-280.

20. Sealey WM, Barrows FT, Casten M, Hardy RW. Dietary protein source and level affects growth in neon tetras. $\mathrm{N}$ Am J Aquac 2009; 71(4):320-324.
21. Afzal Khan M, Jafri AK, Chadha NK. Effects of varying dietary protein levels on growth, reproductive performance, body and egg composition of rohu, Labeo rohita (Hamilton). Aquacult Nutr 2005; 11(1):11-17.

22. Chong ASC, Hashim R, Ali AB. Assessment of dry matter and protein digestibilities of selected raw ingredients by discus fish (Symphysodon aequifasciata) using in vivo and in vitro methods. Aquacult Nutr 2002; 8(3):229-238.

23. Meffe GK, Snelson JFF. Lipid dynamics during reproduction in two livebearing species, Gambusia holbrooki and Poecilia latipinna. Can J Fish Aquat Sci 1993; 50(10):2185-2191.

24. Tamaru CS, Ako $\mathrm{H}$, Paguirigan R. Essential fatty acid profiles of maturation feeds used in freshwater ornamental fish culture. Hydrobiologia 1997; 358(1):265-268.

25. Hemre GI, Mommsen TP, Krogdahl A. Carbohydrates in fish nutrition: effects on growth, glucose metabolism and hepatic enzymes. Aquacult Nutr 2002; 8(3):175-194.

26. Krogdahl A, Hemre GI, Mommsen TP. Carbohydrates in fish nutrition: digestion and absorption in postlarval stages. Aquacult Nutr 2005; 11(2): 103-122.

27. Shim KF, Ng SH. Magnesium requirement of the guppy (Poecilia reticulata Peters). Aquaculture 1988; 73(1-4): 131-141.

28. Shim KF, Ho CS. Calcium and phosphorus requirements of guppy Poecilia reticulata. Nippon Suisan Gakkaishi 1989; 55:1947-1953.

29. Ortuño J, Esteban MA, Meseguer J. The effect of dietary intake of vitamins $C$ and $E$ on the stress response of gilthead seabream (Sparus aurata L.). Fish Shellfish Immunol 2003; 14(2): 145-156. 
30. Halver J. The Role of Vitamin C in Nutrition and Fish Health. En: Annual Conference Proceedings - American Zoo and Aquarium Asociation. Seattle WA: 1995.

31. Fracalossi DM, Allen ME, Nichols DK, Oftedal OT. Oscars, Astronotus ocellatus, have a dietary requirement for vitamin C. J Nutr 1998; 128(10):1745-1751.

32. Chávez de Martínez MC. Vitamin C requirement of the Mexican native cichlid Cichlasoma urophthalmus (Gunther). Aquaculture 1990; 86(4):409-416.

33. Shim $\mathrm{KF}$, Tan $\mathrm{CH}$. The dietary requirement of vitamin $A$ in guppy (Poecilia reticulata Peters). En: The current status of Fish Nutrition in aquaculture, the Proceedings of Third International Symposium on Feeding and Nutrition of Fish. Toba, Japan: Japan Translation Center, Ltd.; 1990.

34. Chatzifotis $S$, Pavlidis $M$, Jimeno $C D$, Vardanis G, Sterioti A, Divanach P. The effect of different carotenoid sources on skin coloration of cultured red porgy (Pagrus pagrus). Aquacult Res 2005; 36(15):1517-1525.

35. Sinha A, Asimi OA. China rose (Hibiscus rosasinensis) petals: a potent natural carotenoid source for goldfish (Carassius auratus L.). Aquacult Res 2007; 38(11): 11231128.

36. Wallat GK, Lazur AM, Chapman FA. Carotenoids of different types and concentrations in commercial formulated fish diets affect color and its development in the skin of the red oranda variety of goldfish. N Am J Aquac 2005; 67(1):42-51.
37. Wang $\mathrm{YJ}$, Chien $\mathrm{YH}$, Pan $\mathrm{CH}$. Effects of dietary supplementation of carotenoids on survival, growth, pigmentation, and antioxidant capacity of characins, Hyphessobrycon callistus. Aquaculture 2006; 261(2): 641-648.

38. Baron $M$, Davies $S$, Alexander $L$, Snellgrove D, Sloman KA. The effect of dietary pigments on the coloration and behaviour of flame-red dwarf gourami, Colisa lalia. Anim Behav 2008; 75(3): 1041-1051.

39. Gouveia L, Rema P, Pereira O, Empis J. Colouring ornamental fish (Cyprinus carpio and Carassius auratus) with microalgal biomass. Aquacult Nutr 2003; 9(2): 123-129.

40. Gouveia L, Rema P. Effect of microalgal biomass concentration and temperature on ornamental goldfish (Carassius auratus) skin pigmentation. Aquacult Nutr 2005; 11(1): 19-23.

41. Ezhil J, Jeyanthi C, Narayanan M. Effect of formulated pigmented feed on colour changes and growth of red swordtail, Xiphophorus helleri. Turk J Fish Aquat Sci 2008; 8(1): 99-101.

42. Lim LC, Dhert P, Sorgeloos P. Recent developments in the application of live feeds in the freshwater ornamental fish culture. Aquaculture 2003; 227(1-4): 319-331.

43. Lim LC, Cho YL, Dhert P, Wong CC, Nelis $H$, Sorgeloos P. Use of decapsulated Artemia cysts in ornamental fish culture. Aquacult Res 2002; 33(8): 575-589.

44. Gordon AK, Kaiser H, Britz PJ, Hecht T. Effect of feed type and age-at-weaning on growth and survival of clownfish Amphiprion percula (Pomacentridae). Aquar Sci Cons 1998; 2(4): 215-226. 
45. Gordon AK, Hecht T. Histological studies on the development of the digestive system of the clownfish Amphiprion percula and the time of weaning. J Appl Ichthyol 2002; 18(2): 113-117.

46. Coutinho P, Rema P, Otero A, Pereira $\mathrm{O}$, Fabregas $\mathrm{J}$. Use of biomass of the marine microalga Isochrysis galbana in the nutrition of goldfish (Carassius auratus) larvae as source of protein and vitamins. Aquacult Res 2006; 37(8): 793-798.
47. Rodrigues LA, Kochenborger FJB. Influência do processamento da dieta no desempenho produtivo do acará bandeira (Pterophyllum scalare). Maringá 2006; 28(1): 113-119.

48. Harpaz S, Slosman T, Segev R. Effect of feeding guppy fish fry (Poecilia reticulata) diets in the form of powder versus flakes. Aquacult Res 2005; 36(10): 996-1000. 